\title{
研 究
}

\section{障害者の生活向上のためのロボットのニーズに関する調査研究}

\author{
手 嶋 教 之* \\ Survey of the Needs about Rehabilitation Robotics \\ Noriyuki TEJIMA \\ National Rehabilitation Center for the Disabled, Tokorozawa
}

\begin{abstract}
In order to provide some baseline information in the development of robots to help persons with disabilities, a survey was made to find how persons with physical disabilities and therapists felt about rehabilitation robots.

In the 119 replies out of 200 questionnaires to persons with physical disabilities, the results of the survey were as follows.

1) They were generally positive to the robotic aids in their activities of daily living, especially in mobility and transfer to a wheelchair.

2) Although majority of them expressed their acceptance to robotic aids in cooking, having a meal and evacuation. Some of them showed strong refusal.

3 ) One of the noticeable answers described the expectation for better quality of life such as robotic aids in hairdressing.

In the 95 replies out of 200 questionnaires to the physical and occupational therapists, the results of the survey were as follows.

1) Most of them felt it difficult to develop a robot for the training, mainly because of safety, psychological problems and flexible adaptation to respective patient.

2) They expected robotic aids in their activities of evaluation of the training, transfer of the patients, moving and clearing training equipments.

3 ) Most of them felt that robot will be beneficial in the assistance of the daily living of persons with disabilities.
\end{abstract}

\section{Key Words}

Robot, Rehabilitation, Training, Person with physical disabilities, Therapist

\section{1.はじめに}

1987年の厚生省身体障害者実態調査によれば， 全国で240万人の人達が障害と闘っており,この
*正会員 国立身体障害リハビリテーションセンター 厂359 所沢市並木 $4-1$
数は年々増加している11。また全人口に対する 高齢者の割合も增えている。その結果, 近い将 来には医療従事者や介護者が大幅に不足し，医 療・福祉サービスの質及び量の低下が-予想され る。 
これらの問題の解決策の一つとして, 産業界 で広く活用されているロボット技術を福祉分野 に応用する試みが提案されている2 26)。これら の研究は主として医者や工学者によって行われ ているが，このようなロボットに対しては障害 者や医療従事者の二ーズや意見を十分に反映さ せなければならない。セラピストや障害者に対 してロボットに関する意識調査もアメリカやイ ギリスなどで行われたが27),28)，日本人と欧米人 との意識や生活様式の違いもあり，その結果を 日本でそのまま適用することはできないと考え る。

以上の観点から，障害者のためのロボットに 関する障害者及び医療従事者のニーズを明らか にし，今後ロボット技術を福祉分野に適用する ための基礎資料とすることを目的として，アン ケート調査を行った。

\section{2.アンケート調査}

福祉分野にロボット技術を適用した際に最も 恩恵を受けると考えられるのは，障害者のなか でも運動機能障害を持つ人達である。そこで本 研究においては, 対象として肢体不自由者と肢 体不自由者の訓練を行うセラピストに限定し, ロボットに関するニーズをアンケートにより調 查した。肢体不自由者には，ロボットによる介 助・介護を望むか，またその際に介助・介護し てほしい内容などに関して尋ねた。またセラピ ストには，障害者へのリハビリテーション訓練 においてロボットを使用することの可能性など に関して尋ねた。

\section{1 肢体不自由者へのアンケート調査}

\section{1 .1 方 法}

アンケートは平成 3 年 1 月から 2 月に各人に 郵送し，返信用封筒でその回答を回収した。ア ンケート対象者としては全国の肢体不自由者の 中で特に重度の障害者を中心とし，やや軽度の 者も含めた。送付したアンケートの内容を付録 1 に示す。各人の持つさまざまな意見を集める ために, アンケートの内容は主として自由記述 方式とした。

\section{1 .2 結 果}

アンケート送付数 200 通, そのうち回収数 119 通, 有効回答数 119 通であり, 有効回答率は 59 . 5\%であった。

回答者の性別構成を図 1 に, 年龄分布を図 2 に示す。回答者の $3 / 4$ が30歳未満と若い人達で あった。また回答者の主たる障害を図 3 に, 障 害の程度を図 4 に示す。全員が障害者手帳を持

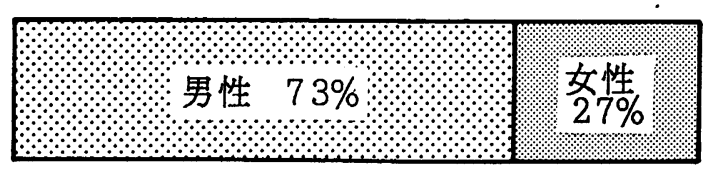

図 1 回答した障害者の性別構成

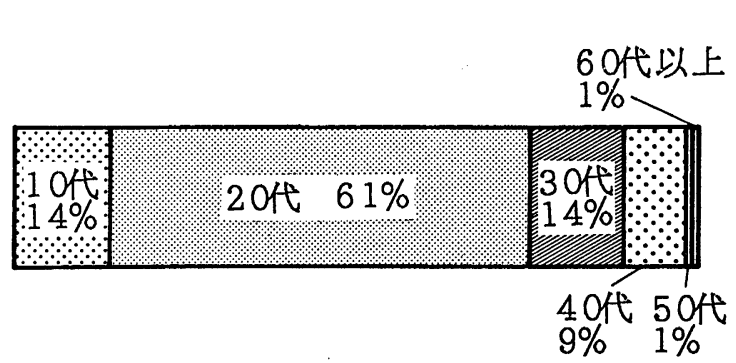

図 2 回答した障害者の年齢分布

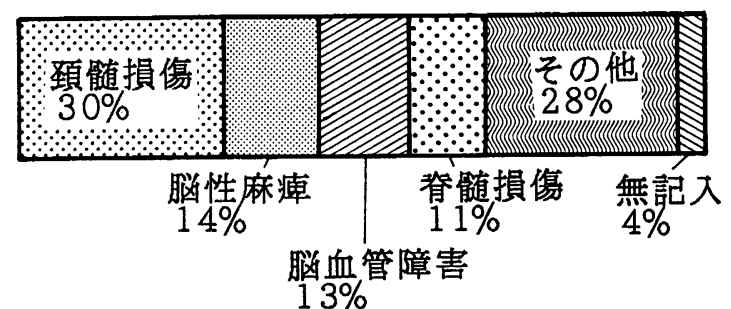

図 3 回答した障害者の主たる障害の種類

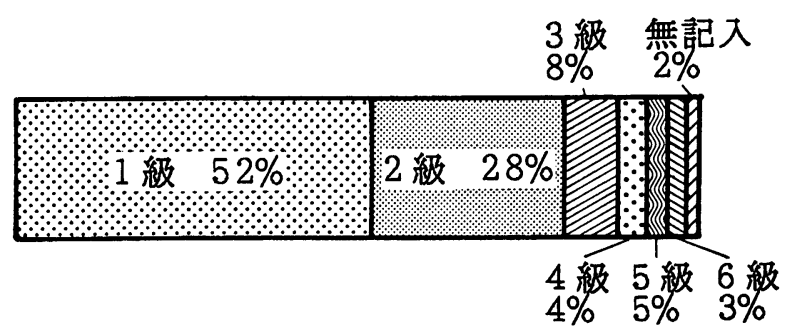

図 4 回答した障害者の障害の等級 
つており， 1 級・2 級をあわせて $80 \%$ と重度の 人が多かった。車椅子の使用状況を図 5 に，仕 事の状況を図 6 に示す。

回答者が一人ではできなくて困っていること についてまとめたものを表 1 に示す。高い所や 低い所にある物をとる，階段や段差を越える， 着替之や炊事，入浴，車椅子への移乗などに困 っている人が多かった。

ロボットによる補助を希望するかに対する回 答を図 7 に示す。 $55 \%$ の人がロボットによる介 助・介護を望んでいたが，望まない人も $27 \%$ い た。

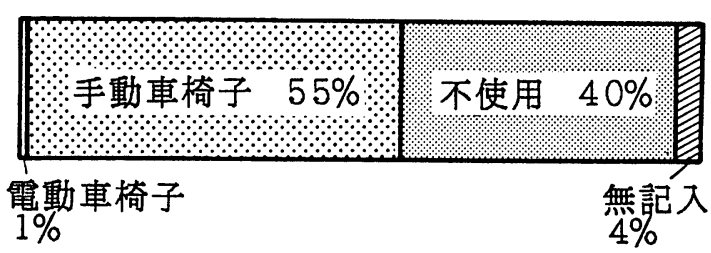

図 5 回答した障害者の車椅子の使用状況

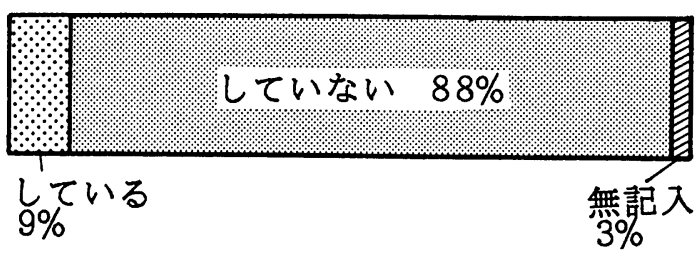

図 6 回答した障害者の仕事の状況

表 1 肢体不自由者が一人でできずに困っているこ と

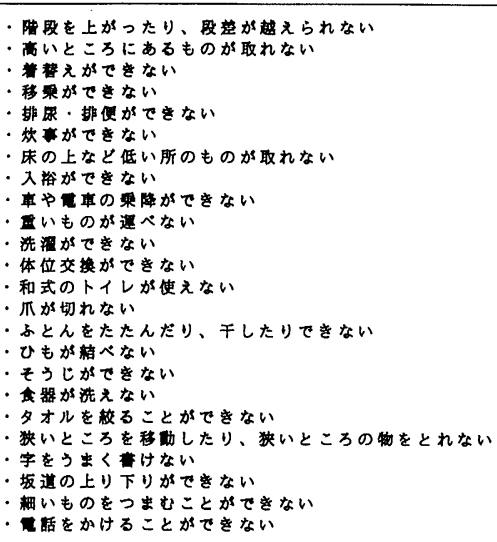

ロボットによって補助してほしいことをまと めた結果を表 2 に示す。さまざまな意見が笴せ られたが，階段昇降の補助，高い所や低い所に あるものをとる，炊事・食事介助，移乗などを 挙げる人が多かった。

回答した肢体不自由者がロボットにはして欲 しくないことを表 3 に示す。ロボットにして欲 しくないことを挙げた人の数は多くない。排 尿・排便介助，炊事，食事などが挙げられた。 なかには全部して欲しくないという回答もあっ た。

\section{1 .3 考 察}

ロボットに介助してほしいことに関してはさ まざまな意見がよせられた。この中で特に多か った意見は移動・移乗，日常生活動作，生活関

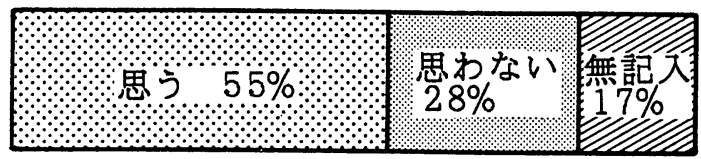

図7自分一人ではできないことを障害者がロボッ トに介助して欲しいと思うかどうかのアンケ 一ト結果

2 肢体不自由者がロボットがやってくれると便 利と考えるもの

\begin{tabular}{|c|c|}
\hline 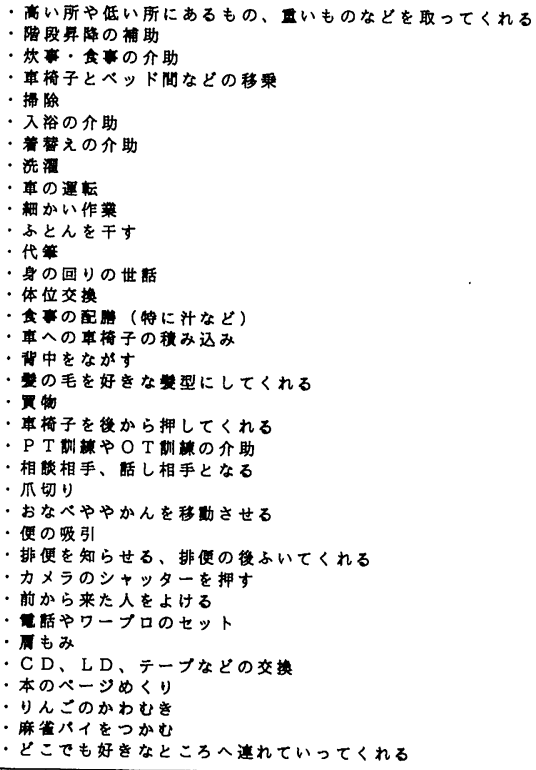 & 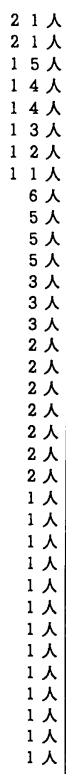 \\
\hline
\end{tabular}


表 3 肢体不自由者がロボットにはしてもらいたく ないこと

\begin{tabular}{|c|c|}
\hline 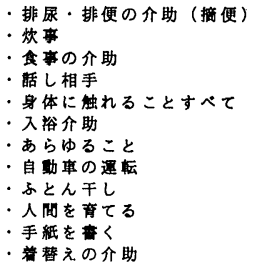 & 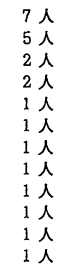 \\
\hline
\end{tabular}

連動作に関するものであった。これらは暮して いく際にできなければ困る作業であり，障害者 の介助・介護を行うロボットにおいては最優先 で解決されるべきであると考える。

多くの人達が希望する作業を行うロボットの 開発は非常に重要なことであるが, 少数の人か らよせられた意見も重要視しなければならない。 例えば「好きな髪型にしてくれるロボット」な どは今までの研究では全く考えられてないと思 われる。しかし障害者であってもおしゃれをし たいのは当然であり，ロボットによって行うべ きかは問題であるが，これらをも実現してこそ 本当の福祉と言えるのだと考える。将来的には このように障害者の多様なニーズの一つ一つに 対応する必要があると考之る。

アンケートの結果で最も興味深い点は，ある 人にとってロボットに介助してほしいことが， 他の人にとっては介助してほしくないことであ る場合があるという点である。例之ば炊事・食 事は介助してほしいと回答した人が15人いたが, これを介助してほしくないと回答した人も 5 人 いた。例えばその中の 1 人は「おいしくても味 気ないからいやだ」と述べている。また介助し てほしくないとの回答の多い作業に排便・排尿 の介助があるが，これらの介助を強く望む声も 多く，その中の 1 人は自分なりのアイデアを述 べた後で「もし完成したら被験者 1 号になって もよい」と書き記している。このように障害者 各人の障害部位・障害レベル, 生活環境, 性格 などによってその希望する介護・介助と希望し ない介護・介助とが大きく異なることがわかっ た。

このことはこの分野のロボット研究・開発に
おいて，少数の障害者の意見を聞いただけでは 偏ったロボットしか開発されないことを示して いる。その結果, 他の障害者は使用しないだけ でなく，逆にこのようなロボットに嫌悪感さえ 覚える可能性もある。また普及においても, 各 障害者の意見をよく聞き，最も適したロボット を処方することが重要であると考える。

アンケートの回答を見ると, 各人のロボット に対するイメージが大きく異なることがわかっ た。漫画に出てくるような何でもできるロボッ トを考える人もいれば，ただの装置という意味 で考えることもあった。アンケートの中でロボ ットに介助してほしくないと回答した人の中に は「ロボット」という言葉に対する「冷たい」

「堅い」「機械的だ」といった先入観によるもの と考えられる意見が多く見られた。親しみのあ る外観や肌触りなども今後のロボット開発の重 要なテーマとなるとともに，このような先入観 からロボットが使用されない状況を作らないよ うな方策を考之る必要がある。

ロボットには介助してほしくないと回答した 人が33人いたが, この人達の回答を分析したと ころ，32人は特に困っていることがない，又は ロボットで介助してもらうほどではないという 人達であった。残りの 1 人は実際に多くの事で 困っているにもかかわらず，口ボットによる介 助を望んでいなかった。この詳しい理由は不明 であるが，50歳という年龄からくるものかも知 れないと考えている。

今回の調査では対象が肢体不自由者のみであ ク，またその中にはいわゆる寝たきり障害者は ほとんど含まれていなかった。障害の程度や部 位によってその必要とする介助・介護が大きく 異なることを考え, 今後は対象者を拡大した調 査が必要であると考えている。

\section{2 セラピストへのアンケート調査}

\section{2 .1 方 法}

アンケートは平成 3 年 1 月から 2 月に各人の 所属する全国の施設に郵送し，返信用封筒でそ の回答を回収した。アンケート対象者としては 理学療法士（以下 PT と略す）及び作業療法士 （以下 OT と略す）とした。送付したアンケー 
トの内容を付録 2 に示す。各人の持つさまざま な意見を集めるために，アンケートの内容は主 として自由記述方式とした。

\section{2 .2 結 果}

アンケート送付数は PT・OT 各100通の合計 200通で, そのうち回収数99通, 有効回答数95通 であり，有効回答率は $47.5 \%$ であった。

回答者の性别棈成を図 8 に，年齢分布を図 9 に示す。また，回答者の主たる職務を図10に示 す。その他の中には複数の PT·OT の意見をま とめた回答が 2 件含まれる。回答者が一週間に 一人でみる患者・障害者の数を図11に示す。一 週間にのべ 100 人以上の患者をみている者が四 割近くいた。

思者・障寒者の訓練の中で特に困っているこ とに関してまとめた結果を表 4 に示す。特に意 兒が多かった点は, セラピストの人数不足, 障

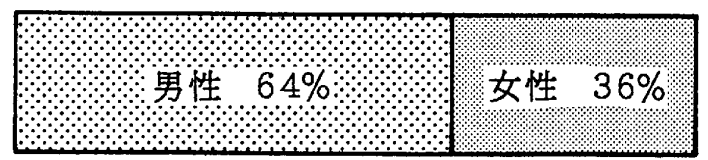

図 8 回答したセラピストの性別構成

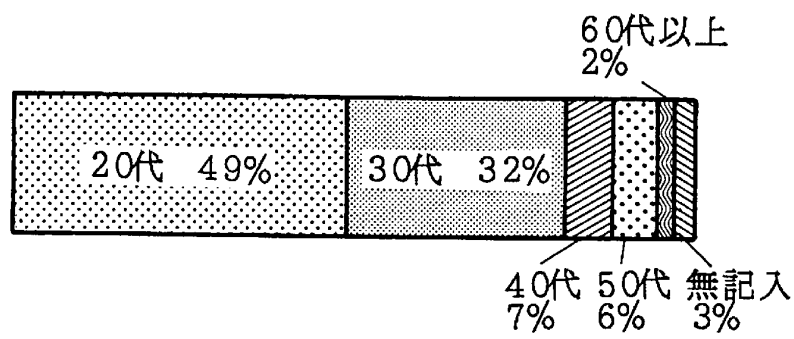

图 9 回答したセラピストの年龄分布

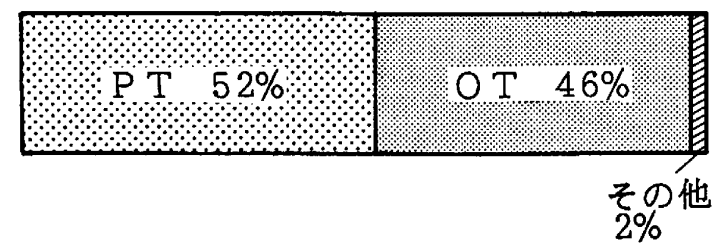

図10 回答したセラピストの主たる職務

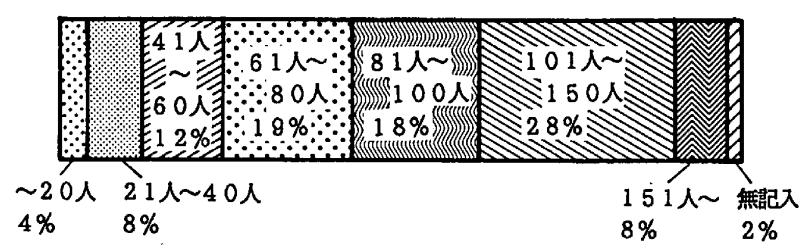

図11 回答したセラピストが 1 週間にみる患者・障 啨者ののべ人数

表 4 セうピストが郡練において困っていること

\begin{tabular}{|c|c|}
\hline 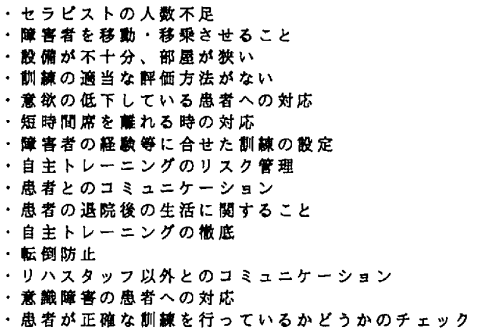 & 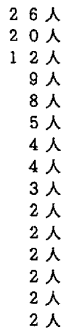 \\
\hline
\end{tabular}

害者の移動・移乗に関わる問題，設備の問题， 訓練の評価に関してなどであった。

訓練作業の中で将来ロボットに手伝わせるこ とができる，又は手伝わせたい作策を集計した 結果を表 5 に示す。さまざまな意見がよせられ， その多くに長文の説明がついていた。

訓練の一部をロボットに行わせた時に考えら れる利点を表 6 に示す。訓練作業の省力化, 訓 練成果の数值化, 重学働の軽減の 3 点に関して は60\%以上の人が利点として挙げていた。しか し㚣全の監視および訓練意欲の促進に関しては 難しいであろうという意見が多かった。それ以 外の意見はほとんどなかった。

訓練作業を行わせるロボットを開発する際に 注意すべき点や必要な機能に関する意見を表 7 にまとめた。多様な意見がよせられたが，安全 性の確保，操作性，患者の状態の把握，低価格 などの意見が多かった。

また患者・障害者の訓練作業の中でロボット に行わせることができないとセラピストが考え る作業について表 8 に示す。心理・精神的側面 のサポート，患者の時々刻々の反応に応じた対 応の必要な訓練は，それぞれ約 $30 \%$ のが行わ せることができないと指摘した。 
表 5 セラピストが费者・障害者の訓練作業の中で 将来手伝わせることができる作㧛, 又は手伝 わせることができればよいと考える作業

\begin{tabular}{|c|c|}
\hline ・車掎子・ベッド間などの移棌 & 33 人 \\
\hline ·関節可動娀期練 & 24 人 \\
\hline ·歩行介助、歩行䐓練 & 23 人 \\
\hline ・バイタルサインや安全の監視 & $19 人$ \\
\hline 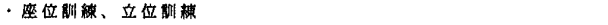 & 17 人 \\
\hline ·膃力缯化敖練 & 15 人 \\
\hline ・㖄練成果なとの評価、定量化 & 13 人 \\
\hline ・綵り返し回数、時成などの测定 & 7 人 \\
\hline ・道具の器镧、片付け & $7 \curlywedge$ \\
\hline ・瞓練咅、漰室咸の送迎 & 7 人 \\
\hline · A D L 介助 & 5 人 \\
\hline ·反後作栗一般 & $4 \lambda$ \\
\hline ・クループセラピー & 4 人 \\
\hline ・ゲームの相手 & 3 人 \\
\hline ·体位交撂 & $3 \hat{人}$ \\
\hline ・意欲向上のためのロボット & 2 人 \\
\hline ・唄練の眖明、指运 & 1 人 \\
\hline 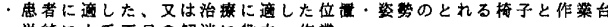 & $1 \curlywedge$ \\
\hline ・単純に人手不足の解消に役立つ作業 & 1 人 \\
\hline ・呼吸籶槏 & 1 人 \\
\hline ·排泄㘯介助 & 1 人 \\
\hline ・サイベックスのような単純負荷的作筃 & 1 人 \\
\hline ・年引、ホットパック作成などの単純作䍶 & 1 人 \\
\hline 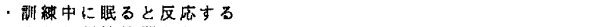 & 1 人 \\
\hline ・小さな㓩練機器をもってくる & 1 人 \\
\hline ・エレベータに乗れない者への付添 & 1 人 \\
\hline ・マッサージ & 1 人 \\
\hline ・カルテ政理 & 1 人 \\
\hline ·失禁の後始末などの雓用 & $1 \curlywedge$ \\
\hline ・レクリエーション面 & 1 人 \\
\hline ·水中機能唄練 ～ & 11 \\
\hline ・おむつの交換 & 1 人 \\
\hline - 洗褧 & $1 \lambda$ \\
\hline 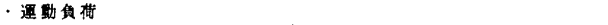 & 1 人 \\
\hline ・リハビリテーション訓殔 作成プログラム & 1 人 \\
\hline
\end{tabular}

表 6 セラピストは訓練の一部をロボットに行わせ ればどのような利点があると考えるか

\begin{tabular}{|c|c|}
\hline 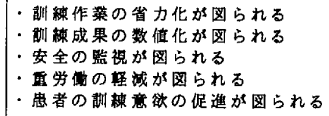 & $\begin{array}{ll}6 & 4\end{array}$ \\
\hline
\end{tabular}

表 7 訓練を行わせるロボット開発に際してセラピ ストが注意すべきと考える点又は必要だと考 える機能

\begin{tabular}{|c|c|}
\hline 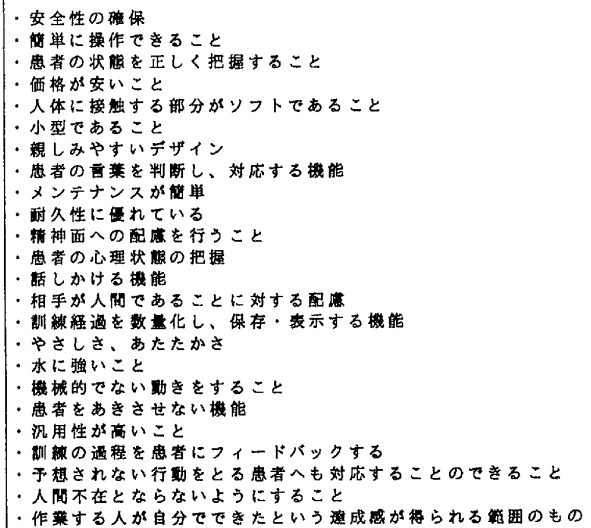 & 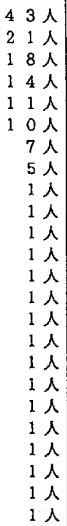 \\
\hline
\end{tabular}

表 8 セラピストが患者・障害者の訓練の中でロボ ットには行わせることができないと考えるこ と

\begin{tabular}{|c|c|}
\hline 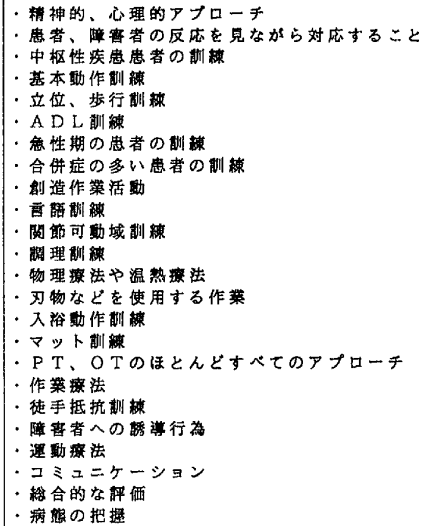 & 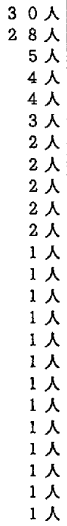 \\
\hline
\end{tabular}

\section{2 .3 考 察}

回签したセラピストの一般的な意見は，障害 者のリハビリテーション訓練を行うロボットの 実現は難しいだろうというものであった。その 主たる理由は，患者・障害者毎の違いに対する 対応が難しい点であつた。訓練方法は患者の障 害部位や性格，生活環境などによって大きく異 なりまたその日の患者の状態(顔色，血王等) によっても訓練プログラムを変える必要がある。 このような作業を行うロボットよりは，在宅障 害者等の介護・介助用ロボットの方が実現が容 易ではないかという意見が多かった。訓練中に 突然予測もしないことをする患者への対応の難 しさを指摘する意見もあった。

リハビリテーション訓練は人間が行うことが 重要なのだという意見も多かった。訓練垒は社 交の場であり，ここでのコミュニケーションが 重要であって，それをロボットで㫪現すること はできないという意見である。特に老人では口 ボットによる訓練を希望する人はいないであろ うという意見も多かった。

このように多くのセラピストが訓練用ロボッ 卜の実現に否定的な見解を示している一方では， 訓練以外におけるロボットに対する期待は大き かった。多くの施設や病院では患者の人数の割 にセラピストの数が少なく，訓練に十分な時間 
がさけないという意見がよせられた。このため 訓練以外の作業でのロボットの補助には多くの 期待がよせられた。具体的には，訓練成果の定 量化, 訓練室・病公間の移動の補助, 道具の準 備・片付けなどが挙げられた。また訓練におい ては作業療法よりは理学療法の方がロボット技 術を適用しやすいとする意見が多かった。

\section{3. 考察}

障害者及び障害者を訓練するセラピストのそ れぞれから，ロボットに関するさまざまなニー ズや要望がよせられた。両者ともロボットに対 して大きな期待を持っている人が多いことがわ かった。

セラピストでは，障害者と直接ふれ合う部分 はロボットに任せることはできないという意見 がほとんどであった。ロボットに対する期待は 訓練作業に伴う雑用に対寸るものが多かったが, それと同様に家庭内で障害者を介助・介護する ロボットに関する期待も高かった。

セラピストがいかに訓練を行っても，家庭に 㞔ってから葠たきりになってしまう。又は家に
介護者がいないために施設に入院したままにな るという人達が多い。このような人達のために も，訓練を行うロボットよりも介助・介護ロボ ットの開発を㱡先すべきだという意見である。 また優れた介助ロボットができれば，障害の受 容も容易になり，訓練の意欲向上も期待できる という意見もあった。

訓練作業では強制的に関節を風伸させたり， 体重を支えたりなど大きな力で人体に働きかけ る作業が多い。この点においても訓練ロボット よりも介護・介助用ロボットの方が実現が容易 であろうと考之る。これらを考虑すると，特に 在宅障害者の介助・介護ロボットを優先的に研 究・開発すべきであると考える。

回答した障害者の意見の多くも介助・介護口 ボットの実現に期待するというものであった。 回答を返送しなかった人を含めても， 3 人に 1 人はロボットによる補助を望んでいることにな る。今後できるだけ早い時期に有効な介助・介 護ロボットを開発することが，障害者の生活向 上に必要不可欠であることが示された。

付録 1 肢体不自由者へのアンケート

記入日

平成 年 月 日

1. 氏名

2. 性別 1）男

2）女 明治

3. 生年月日 大正年 月 日生 満 歳 昭和

4. 現住所

5。主たる障害
1 ）脳血管障害
2 ) 頸髄損傷
3) 脳性麻痹
4) その他(

6. 障害者手帳を
1）所持している(等級）
2) 所持していない

7. 現在車椅子を使用していますか

1）電動車椅子を使用

2 ) 手動車椅子を使用

3 ) 不使用
8. 現在なんらかの仕事を
1) している
2) していない

9. 仕事や日常生活の中で自分一人ではうまく できなくて困っていることがあればいくつで も具体的に書いて下さい。

10.9の困っていることを補助するロボットが あればよいと
1 ）思う
2) 思わない

11. そのほかに仕事や日常生活の中でロボット がやってくれれば便利になると思うことがあ ればいくつでも具体的に書いて下さい。

12. 日常生活の中でロボットにはしてもらいた くないと思うことがあればいくつでも具体的 に書いて下さい。

13、そのほか何かございましたら自由に書いて 下さい。 


\section{4. 結論}

障害者の生活を向上させるためのロボットに 関する障害者及びセラピストのニーズをアンケ 一トにより調査した。その結果，リハビリテー ション訓練を行うロボットよりも介護・介助用 ロボットの開発が強く望まれていること，障害 者の多様なニーズに対応することができるロボ ットが必要であること, 移動・移乗や日常生活 動作などを補助するロボットが最優先で開発さ れるべきであることがわかった。

尚, 本研究は平成 2 年度厚生科学研究費によ って行われた。本研究を行うにあたって貴重な ご意見やご協力を賜りました国立身体障害者り ハビリテーションセンター山内繁, 中嶋富美子, 杉江勝憲, 植木章三, 廣瀬秀行の各氏に深謝す る。

\section{参考文献}

1）平成 2 年版厚生白書：厚生省編。

2）大島徹，市川洌：Rehabilitative robotics の現状；BME 3：11-17, 1989.

3) M Gilbert and R Foulds : Robotics at TUFTS-New England Medical Center A Progress Report-, Proceedings of the RESNA 10th Annual Conference, 778780, 1987.

4) $\mathrm{C} F u$ : An Independent Vocational Workstation for a Quadriplegic, Proceedings of the RESNA 9th Annual Conference, 182-184, 1986.

5) HH Kwee, JJ Duimel, JJ Smits, AA Tuinhof de Moed, JA van Woerden and LW Kolk : The MANUS Wheelchair-

付録 2 セラピストへのアンケート

記入日 平成 年 月 日

1. 氏名

2. 性別

1）男

2) 女

3 . 年齢 満 歳

4. 所属施設名

5 . 所属施設住所

6. 職務内容
1) $\mathrm{PT}$
2) $\mathrm{OT}$
3) その他 (

7. 1 週間に 1 人でのべ何人の患者・障害者の 訓練を行っていますか。
1) $\sim 20$ 人
2) $21 \sim 40$ 人
3) $41 \sim 60$ 人
4）61 80 人
5) $81 \sim 100$ 人
6) 101 150人
7） 151 人以上

8. 患者・障害者の訓練のなかで特に困ってい ることがあればいくつでも具体的に書いて下 缶い。

9.患者・障害者の訓練作業の中で将来ロボッ トに手伝わせることができる作業，または口 ボットに手伝わせることができればよいと考 える作業がありましたらいくつでも具体的に
書いて下さい。

10. 患者・障害者の訓練の一部をロボットに行 わせたとすると，どのような利点があると考 えられますか。(複数回答化)
1) 訓練作業の省力化
2 ) 訓練成果の数值化
3 ）安全の監視
4) 重労働の軽減
5 ）患者の訓練意欲の促進
6 ）その他 (

11. 患者・障害者の訓練作業を行わせるロボッ トを開発する際に特に注意すべき点や必要な 機能があればいくつでも具体的に書いて下さ い。

12. 患者・障害者の訓練作業の中で，ロボット には行わせることはできないと考える作業が あればいくつでもその理由をつけて具体的に 書いて下さい。

13. その他リハビリテーションロボットに関し てお考えの事がありましたら書いて下さい。 
Mounted Manipulator: Developments Towards A Product Model, ICAART88: 460-461, 1988.

6) J Hammel, $\mathrm{K}$ Hall, D Lees, L Leifer, M Van der Loos, I Perkash and R Crigler : Clinical evaluation of a desktop robotic assistant, J Rehabil Res Dev $26: 1-16$, 1989.

7) DS Lees, R Crigler, M Van der Loos and L Leifer : A Third Generation Desktop Robotic Assistant for the Severely Physically Disabled, ICAART88: 450451, 1988.

8) MR Hillman : A feasible study of a robot manipulator for the disabled, J Med Eng Technol, $11: 160-165,1987$.

9) C Stammers, G Pullin, A Gammie, M Hillman and R Orpwood : A Robot System for the Disabled User, JRSJ 8 :611-614, 1990.

10) WS Harwin, A GINIGE and R Jackson :A Robot Workstation for Use in Education of the Physically Handicapped, IEEE Trans. Biomed Eng 35 : 127 -131, 1988.

11) RG Gosine, WS Harwin, LJ Furby and RD Jackson : An Intelligent end-effector for a rehabilitation robot, J Med Eng Technol $13: 37-43,1989$.

12) D Khalili and $M$ Zomlefer : An Intelligent Robot System for Rehabilitation of Joints and Estimation of Body Segment Parameters, IEEE Trans. Biomed Eng 35 : 138-146, 1988.

13) JM Detriche and B Lesigne : "MASTER", A New Robotics Aid for the Disabled Persons, JRSJ 8 :607-610, 1990.

14) DM Horowitz and JM Hausdorff : Design of a Human-Machine Intereface of a Voice Controlled Vocational Robotic Work Station, Proceedings of the
RESNA 12th Annual Conference, 117118, 1989.

15) LW Korba, R Liscano and N Durie : An Intelligent Mobile Platform for Health Care Applications, ICAART88: 462463, 1988.

16) SY Nof, GR Karlan and NS Widmer : Development of A Prototype Interactive Robotic Device For Use By Multiply Handicapped Children, ICAART 88 : 456-458, 1988.

17) KA Kristy : Use of Robotic Arm as a Rehabilitation Exercise Partner : A Therapeutic Enhancement, ICAART88: 452-453, 1988.

18）橋野堅: 介助ロボット, 日本ロボット学会 誌, 8：604-606, 1990.

19）大島徽, 市川洌, 林武雄：四肢まU者用マ ニピュレータの開発(第 2 報), 東京都補装 具研究所昭和 62 年度研究報告集, 54-62, 1988.

20）百崎寛, 斎藤之男：リハビリテーションロ ボットに関する研究(第 1 報), 第 8 回日本 ロボット学会学術講演会予稿集, 10071008, 1990.

21）東原孝典, 斎藤之男: 全腕式電動義手 (TDU ys-86) のメカニズムと工学的評 価，バイオメカニズム10：227-237, 1990.

22）青柳誠司，富时英雄，宮下収，前田明志， 石神重信：全腕吊り下げ型動力補装具の開 発, 第11回バイオメカニズム学術講演会子 稿集, 9-12, 1990.

23）大塚彰, 高橋誠, 天野博之, 首藤貴 : 食事 動作介助機器の開発研究 特に, 重度四肢 機能障害者に対して, PT ジャーナル, 25 ： 53-57, 1991.

24）田中道雄，花房弘樹，和田多加夫，才木昭 義, 司馬良一：移動型リハビリテーション 支援装置（運動機能評価・訓練装置）の開 発, 第 8 回バイオメカニズム学術講演会予 稿集, 203-206, 1987.

25）井手隆俊, 赤松功也：医療用ロボット（特 
に歩行訓練用ロボット）の開発と臨床応用， 病態生理 8 : 172-174, 1989 .

26）黑沢豊樹：人間共生形高度看護・介護口ボ ットシステム概要報告, ロボット $50: 36$ 50, 1986.

27) SD Prior :An electric wheelchair mounted robotic arm-a survey of poten- tial users, J Med Eng Technol 14 : $143-$ 154, 1990.

28) $\mathrm{K}$ Glass and $\mathrm{K}$ Hall : Occupational Therapist's Views About the Use of Robotic Aids for People With Disablities, Am J Occup Therapy $41: 745-747,1987$. 